\title{
Socio-Economic Impact of Grabbing Water Bodies: A Sociological Study
}

K.M.Sujauddin Assistant Professor, Department of Sociology, Jagannath University, Dhaka, Bangladesh

Article History

Received: 15.07 .2020

Accepted: 20.09.2020

Published: 25.10 .2020

Journal homepage: https://www.easpublisher.com/easjhcs

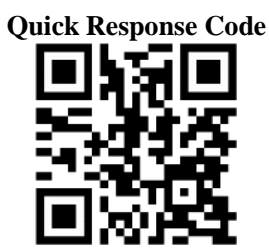

Abstract: Grabbing water bodies is a concerning issues now, as well as a new phenomenon over the last few decades in Bangladesh and often occurring negative impact on local population with different occupations. This research attempts to investigate the grabbing scenario and its consequences on people's life and economy. The study was carried out at the three important water bodies in Dhaka district are the Buriganga river, the Turag river and the Balu river and the data were collected from a sample of 130 participants identified using simple random sampling. Survey research design was followed in this study and the data were collected through face to face interviews. Findings reveal that more than half of the respondents said establishing industry is the main reason of grabbing water bodies. Participants $(77.3 \%)$ reported to have threats to the livelihood pattern while half of the respondents $(55.6 \%)$ rely on water bodies as the sources of livelihoods. The overall scenario represents the worse standard of river management and need to take immediate steps for saving water bodies for our own necessary.

Keywords: Socio-economic, livelihoods, water body.

Copyright (C) 2020 The Author(s): This is an open-access article distributed under the terms of the Creative Commons Attribution 4.0 Internationa License (CC BY-NC 4.0) which permits unrestricted use, distribution, and reproduction in any medium for non-commercial use provided the original author and source are credited.

\section{INTRODUCTION}

Grabbing water bodies is the most important global concerns that can threaten water supply and food security (Ruli, 2012). Water bodies are the wetlands which hold water in all seasons. These are found in all around the world and regarded as "kidneys of the landscape" and "nature's supermarkets" attention to the important ecosystem services (Mitsch \& Gosselink, 2015). Water body is regarded as the most important global commodity for its innumerable uses like drinking, industrial production, irrigation and production of fish, water flow and shellfish (Wang et al., 2011). The economic crisis in 2008 has wielded the scheme to increase grabbing water bodies in worldwide which is driven by states and powerful interests groups with the concentration of food and water security to reduce reliability on market to meet consumptive need (Zerrouk, 2013).

Dhaka is regarded as the capital and prime city of Bangladesh. It is not only the capital city but also the largest city in the country. It is one of the most crowded cities in the world (UN Habitat data, 2013). It is one of mega cities in developing country. A mega city is a metropolitan area with a total population in excess 10 million people (Kotter \& Friesecke, 2009). Dhaka is the world's fastest growing mega city due to rapid urbanization. It will be the sixth largest mega city within 2030 (ICDDR, B, 2014). The city is situated on the bank of the Buriganga river. It was elaborated mainly surrounding the river Buriganga. The city is surrounded by the Buriganga, the Shitolakhya, the Balu and the Turag. The water bodies within the mega city Dhaka was acting as natural drainage system, water reservoir and the river route (Khan, 2012). Water bodies play key role over the agricultural activity and environmental issues. These are the sources of natural surface water. Urban water bodies have some important functions such as: drinking, washing, urban agriculture, cultural purpose, ground water recharge etc. (Laloo et al., 2017). The urban water bodies are mainly the rivers and canals are grabbed by various grabbers for different purposes. Water bodies in and around the capital Dhaka have continuously been grabbed by influential land grabbers backed by politicians. These have also been polluted by unplanned sewerage, drainage system and dumping of waste. Unplanned industrialization is also responsible for grabbing urban water bodies (Mahmud, 2013).

Cities in developing countries, experiencing rapid urbanization, create a number of problems due to rapid and unplanned growth. Urban flooding, pollution of water bodies, depletion of ground water, lack of drinking water and improper sewage disposal are some water related problems encountered due to unplanned urbanization (Nguyen et al., 2017). Dhaka city is growing rapidly by the result of unplanned industrialization. Unplanned industries need a lot of 
area near urban area. Most of the industries are set up near the river because they can emit their wastage into the river and the industries can extend its area toward the river gradually.

The water bodies in Dhaka district are the Buriganga, the Turag and the Balu are on the verge of depth due to continued pollution, encroachment, lack of dredging and illegal sand lifting. About 250 acres of land of these rivers have been grabbed by establishing residential building, industries, brick kilns, mobile towers, market, shops, construction of road, river port and ship building factories (Jibon, 2016). The water bodies are losing their elegancy, liveliness and tradition for grabbing. The rivers turned into a narrow canal. Urban centers rely on water bodies and aquatic ecosystems for various services, such as- oxygen production, carbon storage, natural filtering of toxins and pollutants. Urban water bodies protect from flooding and other related disasters. Aquatic systems dilute and transport pollution away from settlements. Water bodies also maintain the quality of fresh water sources and remove pollutants from the atmosphere (Bahri, 2012). Due to grabbing water bodies in Dhaka city, these services are not done properly. As a result water bodies are filled by pollutions and wastages, so water of these rivers are full of toxin and getting dried up in dry seasons.

\section{Objectives}

The broad objective of this study is to identify the causes and consequences of grabbing urban water bodies in Dhaka city. The most specific objectives of this research are follows-

1. To examine the reasons of grabbing water bodies in Dhaka city.

2. To unearth the socio-economic impact of grabbing water bodies.

\section{Methods ANd Materials}

Field survey was conducted in three different rivers namely the Buriganga, the Turag and the Balu river in Dhaka district. The researcher selected the common people who lived near these rivers and these rivers were purposively selected as areas were easily accessible and most vulnerable for grabbing. An endeavor to get an insight about the nature of grabbing water bodies, researcher followed a triangulation method i.e. a combination of quantitative and qualitative research method. A total number of 130 respondents were chosen using simple random sampling procedure and principle of proportionality. In addition three Focus Group Discussions (FGDs), six Case studies and 3 Key Informant Interviews (KII) were conducted to explore the grabbing impact in different rivers. Besides researcher followed survey research design for data collection which included a semistructured interview schedule containing both open and close ended items,. Afterwards, we pre-tested the interview schedule on 10 respondents as a pilot survey and corrected the interview schedule again to remove anomalies. The data were later collected through formal and informal face to face interviews with the respondents during February, 2019. After the field work, data were re-checked and variables were classified and recoded for data input in SPSS (Statistical Packages for Social Science) and Microsoft Excel. The data were analyzed using descriptive statistics and other graphical presentation techniques.

This study was designed to choose appropriate tool in order to carry out systematic research. Step wise research methods with the objectives of the study were pursued in research plan.

\section{Flow Chart of Research}

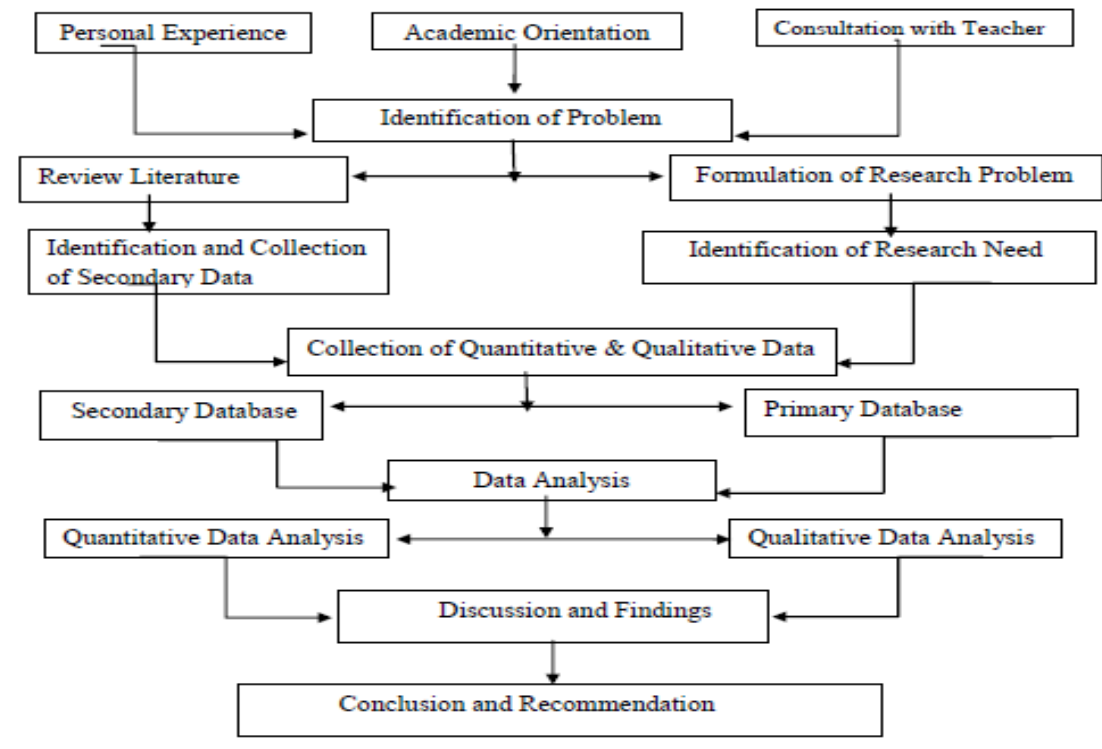




\section{Theoretical Framework}

Political economy is the study of production, trade and their relations with law, custom and government; with the distribution of national income and wealth. Capital is the factor of production. It accumulates commodities which are required for sustaining laborers or engaged in work (Jevons, 1965). Water bodies as capital, which are used for profit maximization. The water bodies are mainly grabbed for economic purpose. The grabbers grab the water body for its commodious facilities as they are available in the sense of economic consideration. We can consider water body as like labor and the grabbers are the capitalists. The grabbers exploit the water bodies whether in capitalist society, the capitalists/ industrialists exploit laborers for profit maximization. The capitalist shifted their location to the water bodies for manufacturing. The shifted of manufacturing is caused by labor force considerations as principle variable (Peet, 1987). The theory of political economy and the city is given by Marx, Weber and Engels. Marx emphasized on the dominance of economic consideration in cultural and political factors affected individual behavior and social history with economic activity. The new classes created by industrial capitalism (proletariat \& bourgeoisie). There not only created two social groups but also identified seven types of new groups by industrial capitalism and they supported government because of their economic and political interests (Marx, 1967). His approach is relevant for the monopoly capitalism as we see displacement of workers, increase immigration, seek lower labor costs and built urban and suburban settlement. Grabbing water bodies is mainly the economic activity supported by powerful actors. Weber emphasized on the dominance of political and cultural factors for city development. Capitalism, as a mode of social organization works through the city space and social relation for the approach of political economy to settlement space. Capitalism created the modern city and the political economy studies social processes within urban space and links to the general level of society (Weber, 1968).Urban water bodies are organized systems of economics, politics and cultures. Political powers and also the city residents grab water bodies and develop city for developing city spaces and use for trade. The political approach is making for economic facilities to settlement space in the water bodies. Engels observed water bodies are the natural resource of the city. Capitalism concentrated on grabbing the water bodies to make easier production and also extended the city for centre to the periphery area. The traditional pattern of the periphery areas are breaking down and created many social problems such as poverty, changing occupation, increasing illegal works etc. The periphery areas of the city are experienced uneven development and extreme poverty. The marginalized people used to live in the water bodies adjacent area for cheap cost. The areas are also faced some critical situation. In this study, political approach has been applied to understand the causes of grabbing water bodies by grabbers like politician, local people, and businessman for capital accumulation.

Water bodies aren't militant as the grabbers take this opportunity for profit. The capitalists choose to locate for labor force consideration to do business because of marketing and production costs and production cost in terms of quality and wage differences of labor (Storper, 1984 \& Walker, 1983). The water bodies are the exclusive places in the city and relatively low prices than other parts of the city. It is easy to transport in water ways than those of other ways and also low cost of transportation. The capitalists want such places where they can do business where they get lower marketing, production and transportation costs as they grab water bodies. The city is defined as a spatial node that concentrates and circulates capital and there is a conflict between capitalist and working class. The economic interests groups bring governmental intervention and get back the principal task of profit making from the space of the city (Harvey, 1976). Capitalist classes may be financial investors, owners of department stores, marketing assets and owners of factories and the working classes are the people who work for a wage. The water bodies are playing as spatial nodes for capital accumulate as these are grabbed by the grabbers. The grabbers can accumulate the spaces without any investment or such very low amount of capital for water bodies. The grabbers some time take lease or buy some parts of land in the low payment instead they use a lot of land towards the water bodies. The spatial impacts changed production process that changed the forms of city. The changes occurred for the socio-spatial relations of business in the city (Scott, 1988). In this study, capital accumulation and conflict theory applied to understand the people's behavior pattern and their socio-economic impact and what are the reasons behind it.

\section{Findings \\ Socio-demographic profile}

In this study most of the respondents were mostly youth aged ranging between 26 to 35 years of old and they are significant in number as it is about $36.2 \%$ where $20.8 \%$ respondents were between $36-45$ years and 46-55 years. These people were the head of their respective household and main earning members in most cases. As the respondents were both male and female, we found that a significant number of respondents were small/petty business $(20.0 \%)$ and where shopkeeper is $13.1 \%$ and female respondents were in maximum case housewife (14.6\%). Besides fisherman and rickshaw puller were the same percentage and that is $10.8 \%$.The result indicates that the young groups of people are more aware about grabbing water bodies and its consequences. The study was conducted mainly with marginalized people who 
live in water body adjacent areas. The participants were not able to uphold any high class job as their educational status was very low. To know the educational status of the respondents' researcher has made an attempt where the study highlights the educational status of the respondents. Most of the participants had completed only primary education $(24.6 \%)$ as well as literate respondents were $22.3 \%$ where S.S.C pass respondents were less proportion $(5.4 \%)$. Education is such a factor that can influence the knowledge, customs, capabilities and habits of the people belonging in any specific area. We can fill our demands through the economic support also can reduce risk through economic support. So economy is crucial in case of studying with any community. Most of the respondents reported that the monthly household income of the respondents is about $41.54 \%$ respondent's income nearly 10001-15000 taka which is very poor amount to maintain a standard life as their family size is also large (Table 1).

Table 1: Socio-demographic profile of the respondents

\begin{tabular}{|c|c|c|c|c|c|c|c|}
\hline \multicolumn{2}{|l|}{ Age } & \multicolumn{2}{|l|}{ Occupation } & \multicolumn{2}{|c|}{ Educational Status } & \multirow{2}{*}{$\begin{array}{l}\text { Monthly } \\
\text { income } \\
\text { Criteria }\end{array}$} & \multirow{2}{*}{$\begin{array}{l}\text { Household } \\
\text { Percent }\end{array}$} \\
\hline Criteria & Percent & Criteria & Percent & Criteria & Percent & & \\
\hline \multirow[t]{2}{*}{$16-25$} & 13.8 & Service & & Primary & 24.6 & $1-5000$ & .769 \\
\hline & & Holder & 10.0 & & & & \\
\hline \multirow[t]{2}{*}{$26-35$} & 36.2 & Small/ & & High school & 14.6 & $5001-10000$ & 18.46 \\
\hline & & petty business & 20.0 & & & & \\
\hline $36-45$ & 20.8 & Shopkeeper & 13.1 & S.S.C & 5.4 & $10001-15000$ & 41.54 \\
\hline $46-55$ & 20.8 & Day labor & 10.0 & H.S.C & 4.6 & $15001-20000$ & 16.15 \\
\hline \multirow[t]{6}{*}{$56 \&$ above } & 8.5 & Fisherman & 10.8 & B. A \& above & 7.7 & $20001+$ & 23.08 \\
\hline & & Rickshaw & & Literate & 22.3 & & \\
\hline & & Puller & 10.8 & & & & \\
\hline & & Unemployed & 3.1 & Illiterate & 20.8 & & \\
\hline & & House-wife & 14.6 & & & & \\
\hline & & Student & 3.1 & & & & \\
\hline Total & 100 & Total & 100 & Total & 100 & Total & 100 \\
\hline
\end{tabular}

Source: Fieldwork, 2019

\section{Grabbing water bodies}

The reason of grabbing water bodies are many and also people from different aspect of society more or less are involved in grabbing. Grabbers of the water bodies may be various people in the study area. So the researcher took multiple response in this question from 130 respondents.

Table 2: Causes of grabbing water bodies

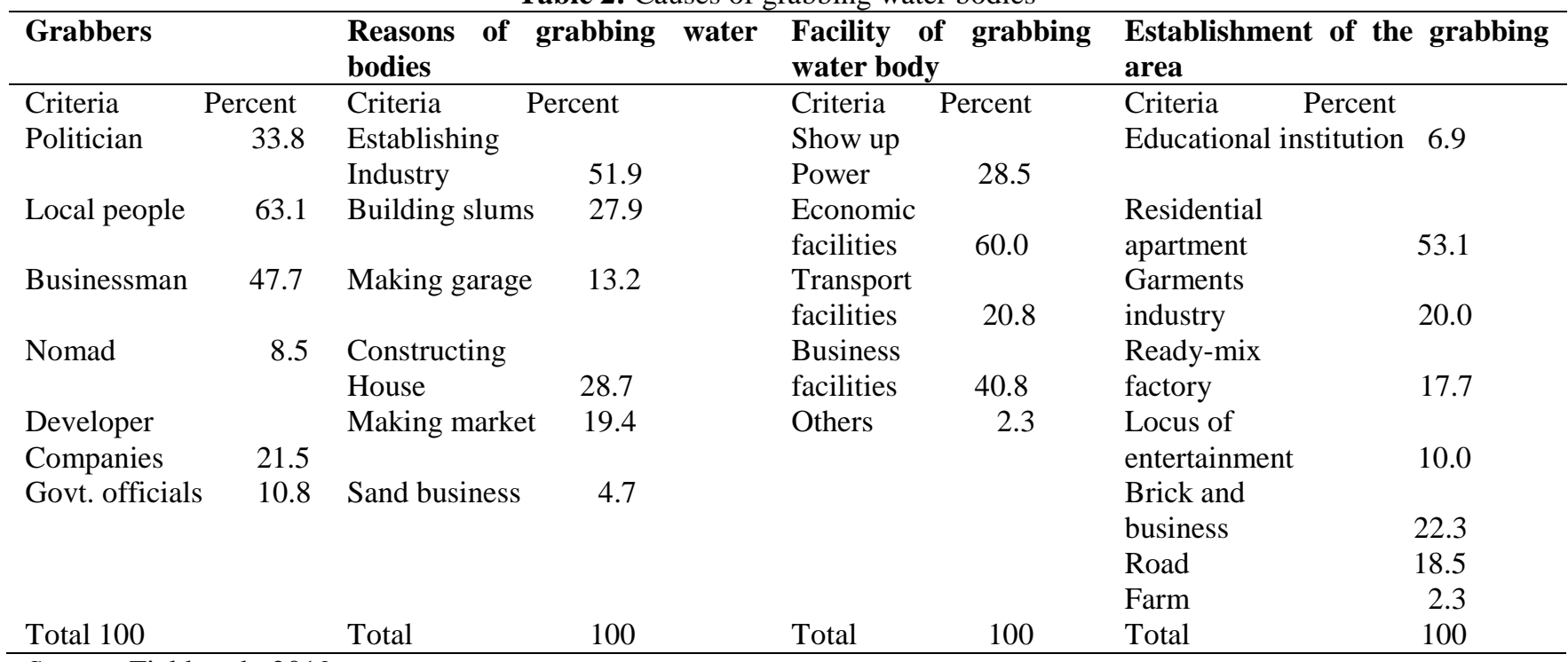

Source: Fieldwork, 2019

Grabbing water bodies is illigal and it hampers our environment very badly. There are so many occupational people who are directly or indirectly relatd to grabbing water bodies. In this case most of the respondents said that local people $(63.1 \%)$ were responsible for grabbing. As they were living here they knew the situation and sometimes they exercise power to grab the water bodies. Basides near about fifty 
percent of the participants descried that businessman $(47.7 \%)$ for their multidimentional task they used water bodies. Morover politician, developer companies and govt. officials were also responsible for this grabbing. It had been said that by the respondents that industry establishment $(51.9 \%)$ is their main target to grab water bodies and the second highest portion of respondents identified house construction $(28.7 \%)$ either it could be slum or normal house. Grabbing water bodies is not a good job at all rather it's a worse one. According to the people of the locality they also shared their opinion in response to the facilities of grabbing water bodies. Respondents reported that grabbing occurs for economic facilities $(60 \%)$, besides near about fifty percent that facilitate business facilities (40.8\%). The study focus that the grabbing water bodies has its use in establishing the structures in many kinds of activities. With multiple responses of the respondents the study reveal most of the respondents (53.1\%) establish residential apartment, $22.3 \%$ establish brick and sand business, 20\% establish garments industry, $18.5 \%$ response to constructing road, $17.7 \%$ reply for ready-mix factory, $10 \%$ answer for locus of entertainment, $6.9 \%$ answer for educational institution and $2.3 \%$ reply for farming (Table 2).

\section{Water body impact}

Grabbing water bodies, environment and local people all are interrelated to one another. So it has a great impact on society as well as people of that society. It may hamper regular way of life that creates risk and crisis also. Especially local people's livelihoods are in danger. In this study socio-economic impact decorated with multiple responses of 130 respondents.

Table 3: Respondents and their impact of grabbing water body

\begin{tabular}{|c|c|c|c|c|c|c|c|}
\hline \multicolumn{2}{|c|}{ Socio-economic impact } & \multirow[t]{2}{*}{$\begin{array}{l}\text { Involve in } \\
\text { occupation }\end{array}$} & \multirow{2}{*}{$\begin{array}{l}\text { n new } \\
\text { Percent }\end{array}$} & \multicolumn{2}{|c|}{$\begin{array}{l}\text { Entertainment in water } \\
\text { bodies }\end{array}$} & \multicolumn{2}{|c|}{$\begin{array}{l}\text { Financial crisis for } \\
\text { grabbing water bodies }\end{array}$} \\
\hline Criteria & Percent & & & Criteria & Percent & Criteria & Percent \\
\hline Threats to & & Cattle rearing & 12.8 & Boat journey & 32.6 & Reduction & \\
\hline Livelihood & 77.3 & & & & & income & 30.91 \\
\hline $\begin{array}{l}\text { Social } \\
\text { migration }\end{array}$ & 46.4 & Day labor & 43.6 & Boat race & 10.5 & $\begin{array}{l}\text { Increasing } \\
\text { food cost }\end{array}$ & 35.45 \\
\hline $\begin{array}{l}\text { Mental } \\
\text { pressure }\end{array}$ & 40.9 & Service holder & 1.1 & $\begin{array}{l}\text { Passing } \\
\text { leisure }\end{array}$ & 45.3 & $\begin{array}{l}\text { Shortage of } \\
\text { food }\end{array}$ & 2.73 \\
\hline Threats to the & & Fishery & 4.3 & Fishing & 11.6 & Insufficiency & \\
\hline Entertainment & 28.2 & & & & & of work place & 18.18 \\
\hline Others & 0.9 & $\begin{array}{l}\text { Rickshaw } \\
\text { puller }\end{array}$ & 30.9 & & & $\begin{array}{l}\text { Difficulties in } \\
7.27\end{array}$ & household \\
\hline & & Others & 7.4 & & & $\begin{array}{l}\text { Transportation } \\
3.64 \\
\text { Problem in } \\
\text { fishery }\end{array}$ & problem \\
\hline Total & 100 & Total & 100 & Total & 100 & Total & 100 \\
\hline
\end{tabular}

Source: Fieldwork, 2019

Table 3 indicates that grabbing water bodies is a threat to many reasons. Respondents of this study reported that people have to face threat for livelihoods $(77.3 \%)$. Findings show that local people basically depend on water bodies but if water bodies are grabbed by someone their livelihoods definitely are in danger. Sometimes people migrate $(46.4 \%)$ from the area. When they migrate they take different occupation like cattle rearing, service holder, fishery but most of the time they involve in day laborer $(43.6 \%)$ and rickshaw puller $(30.9 \%)$. The study also shows that in case of attachment between entertainment and water bodies, most of the people $(45.3 \%)$ pass leisure time in the water body; when another $(32.6 \%)$ use water bodies as journey by boat, $11.6 \%$ for fishing and $10.5 \%$ answer for boat race. In the question of facing any economic crisis due to the grabbing by the common people of the study area focuses that the respondents face economic crisis. In regarding their economic crisis about $35.45 \%$ face the problem of food cost as it is increasing, as we know that their job to some extent vulnerable and their daily income fluctuate, so they were not able to adjust the increasing cost. Besides respondents also reported that their income is decreasing day after day and its ratio is mentionable that is $30.91 \%$ and along with this the less crisis they actually face is the problem in fishery $(1.82 \%)$ for grabbing water bodies

\section{DISCUSSION}

The present study investigates the causes and its impact on local people who live near the water bodies like the Buriganga,the Turag and the Balu river in order to explore such a significant subject matter. The study identifies various elements of the water bodies such as water quality, fishes, plants, lives etc. and reveals the consequences on these elements and also livelihoods on people's occupation. The study has been conducted in the adjacent areas of three significant water bodies in Dhaka district. Findings of this study suggest that most of the local people living adjacent to 
water bodies are poor and vulnerable because the people having less income and asset. Sometimes they fail to maintain their family with economic crisis and on an average their income in every month is 10000 to 15000 BDT. Basically there were no suitable job there and they have to depend on water bodies for their occupation. Sometimes politician by coercion, businessman by giving lucrative offer, they try to grab the water bodies and their only hidden goals were the capital accumulation any way. Even though government official and specially developer companies show up power, say the local people that they would be benefited by taking business facilities, transport facilities and economic facilities. Local people have nothing to do because they are comparatively low in economic status. But these above mentioned companies or groups later construct different houses, residential companies, bricks and business. Along with this industry is built up by developers or politicians, markets originate but there had not proper sanitation system, drainage system so environment is polluted very badly. This finding is consistent with some previous works that mentioned about economical consideration is one of the major reason for grabbing water body(Franco J. et al., 2014;Islar M., 2012;Bues, A. and Theesfeld, I., 2012;Mowla Q.A \& Mozumder M.A.K., 2015).

Water bodies involve with environment and socio-economic activities. The result relates with previous study. Grabbing water bodies' effects on socio-economic condition .Grabbing water bodies is a great threat to people who are living near water bodies. After grabbing water bodies people were different occupation were endangered and sometimes they had gone another places for their livelihood and they were bound to take another occupation. Respondents described that people face mental pressure and so many environmental problems. Someone takes their occupation like rickshaw pulling, day laborer and service holder. As the environment was polluted they faced many skin diseases and other problems. Their children and family were not able for the medical treatment as their earning was very low. Quarrel and conflict were common because their occupation were in risk and sometimes had to depend on others. Besides we know that water bodies are the source of entertainment also. People of different areas visit water bodies by boat, sometimes boat race is held in any occasion, people enjoy very much. In any vacation it becomes a crowd place for passing leisure time. But the above mentioned sources of entertainment decrease day by day due to grabbing water bodies. People face many difficulties like food shortage, insufficient work place and increase value of food cost because of their low level of income. This finding of the study suggests previous work (Kabir, R., 2014, Baki, M.A. et al., 2015, Sahaasrabuddhe, K. et al., 2003). As we know all that addressed problems related to water bodies need to solve immediately and government should take urgent steps to recover this vulnerable situation.

\section{CONCLUSION}

AND

\section{RECOMMENDATIONS}

Water bodies are the heart of any territory but new urban economy has destroyed it in the various purposes rising new political economy. Dhaka is the capital and largest city in Bangladesh. The city is naturally bordered by the water bodies. It is only one city in which border surrounding by some big rivers as the Buriganga, the Turag and the Balu River. The river is regarded as water body, is extremely invaded for the expansion of capitalism, unplanned urbanization and industrialism. The water body is invaded by grabbing and pollution for the expansion of city from centre to periphery. The reason for expansion is to manage living area for the increasing population and behind it also for taking economic advantages from the water body. The ultimate reason for grabbing the water bodies is to make profit with mismanagement. Sometimes water bodies regards as the crime place and many local people of different ages do the crime and ultimately suffer more the general people. Water bodies are the important elements of environment and socio-economic aspects of life. The poverty stricken people become poorer due to urban political economy for expansion of capitalism. Grabbing has negative impacts on the environment and livelihoods of common people. The people use environmental elements like water, land, fish, flora and fauna etc. in maintaining their livelihood activities and benefited. But grabbing creates various problems to getting these services naturally. It created artificial water scarcity in dry season. Besides the people who earn from the water body are also badly affected and compelled to change occupation, somewhere changing habitation. Transportation and communication system is hampered for grabbing water bodies.

This study will be helpful to understand the causes and consequences of grabbing urban water bodies in Dhaka district. The study will also be helpful to the concerned water management authorities of Bangladesh to understand the problems. From the findings of the study, it is possible to point out a number of specific recommendations that may be considered:

- Enhanced public access to information about river law and increasing public awareness about importance of the water bodies.

- Authority should take a seat with local people for save water bodies grabbing. Some awareness program or seminar with local people who live in river adjacent areas should be carried regularly about the importance of river and the negative impacts of grabbing water bodies. 
- Local politics should be fair to stop grabbing water bodies. It can be played an important figure to avoid this problem.

- Government should not have any partiality attitudes to the grabbers if they are powerful. The grabbers should be taken under law and punished in terms of penalty, imprisonment. Grabbers should not be appointed to the high position in the government job.

- River management law should be clear and free from corruption. Increasing implementation of law for avoiding grabbing water bodies.

- Strengthening the local management committee with coordination of government agencies at local level.

- Strengthening legal information for the local level.

- Grabbing is not taking place overnight. It is a slow process. So authority should check water body in time to time. For this purpose permanent visitors should be appointed who will check water bodies regularly

\section{REFERENCES}

1. Bahri, A. (2012). "Integrated Urban Water Management", Global Water Partnership (GWP).

2. Baki, M. A., Islam, M. R., Hossain, M. M., \& Bhouiyan, N. A. (2015). Livelihood status and assessment of fishing community in adjacent area of Turag-Buriganga River, Dhaka, Bangladesh. International Journal of Pure and Applied Zoology, 3(4), 347-353.

3. Bues, A. (2012). "Water Grabbing and the Role of Power: Shifting Water Governance in the Light of Agricultural Foreign Direct Investment", Water Alternatives, 5 (2), pp 266-283.

4. Franco, J., Feodoroff, T., Kay, S., Kishimoto, S., Pracucci, G., \& Santos, R. (2014). "The Global Water Grab: a primer", Transnational Institute for Hands off the Land Alliance.

5. Harvey, D. (1976). "Labor, Capital, and Class Struggle around the Built Environment in Advanced Capitalist Societies", Econ Papers, School of Business, Orebro University. 6 (3), pp 265-295.

6. ICDDR, B. (2014). bdnews24.com

7. Islar, M. (2012). Privatised hydropower development in Turkey: a case of water grabbing?. Water Alternatives, 5(2), 376-391.

8. Jevons, H.S. (1965). "The theory of political economy" New York,A.M. Kelley

9. Jibon, G.M. (2016). "Grabbing Kills Dhaka rivers", THE ASIANAGE, $2^{\text {nd }}$ edition.

10. Kabir, R. (2014). "SOCIAL IMPACT ASSESSMENT OF WATER POLLUTION: A CASE STUDY ON BANGSHI RIVER, SAVAR", Institute of Governance Studies (IGS), Brac university, Dhaka.
11. Khan, E.T.A. (2012). "Dhaka Wasa Supply and Sewage Authority: Performance and Challenges"

12. Kotter, T., \& Friesecke, F. (2009). "Developing urban indicators for Managing Mega Cities", World Bank. University on Bonn.

13. Laloo, S.W.L., \& Ranjan, A. (2017). "Urban development impacts on water bodies: A review in India", International Journal on Emerging Technologies; 8(1), pp 363-370.

14. Mahmud, A.H. (2013). "Water bodies grabbed on 'political backings"'; Dhaka Tribune.

15. Marx, K. (1967). "Capital: A Critique of Political Economy", International Publishers Company, Incorporated, Vol 1

16. Mitch, W.J., \& Gosselink, J.G. (2015). "wetlands"; $5^{\text {th }}$ ed: John Wiley and Sons, Inc, New York, pp: 582 .

17. Mowla, Q.A., \& Mozumder, M.A.K. (2015), "DetorioratingBuriganga River: It's Impact on Dhaka's Urban life", PSC Journal, 2 (2), pp 01-10.

18. Nguyen, H. Q., Radhakrishnan, M., Huynh, T. T. N., Baino-Salingay, M. L., Ho, L. P., Steen, P. V. D., \& Pathirana, A. (2017). Water quality dynamics of urban water bodies during flooding in Can Tho City, Vietnam. Water, 9(4), 260.

19. Peet, R. (1987a). "Industrial Restructuring and the Crisis of International Capitalism", in International Capitalism and Industrial Restructuring, Boston: Allen and Unwin, pp 9-32.

20. Rulli, M. C., Saviori, A., \& D’Odorico, P. (2013). "global land and water grabbing"; Proceedings of the national Academy of Sciences, DOI: 10.1073/ PNAS.1213163110/-0/ DCSupplemental.

21. Sahasrabuddhe, K., Mahabaleshwarkar, M., Joshi, J., Kanade, R., Goturkar, S., Oswal, P., \& Patwardhan, A. (2003, December). Changing status of urban water bodies and associated health concerns in Pune, India. In International Conference on Environment and Health Chennai.

22. Scott, A.J. (1988), "New industrial spaces: Flexible production and regional development in North America and Western Europe", Pion Ltd. Vol. 3

23. Storper, M., \& Walker, R. (1984). "The spatial division of labor: Labor and the location of industries", Sunbelt/ snowbelt: Urban development and regional restructuring, pp 19-47.

24. UN Habitat data. (2013). World Economic Forum.

25. Wang, M.-H. et al (2011), "Research articles published in water resources journals: A bibliometric analysis", Desalination and Water treatment; doi: 10/ 5004/ dwt.2011.242: Vol. 28 pp 353-365.

26. Weber, M. (1968). "Basic Sociological Terms. Economy and Society", G. Roth and C. Wittich. Berkeley, University of California Press. Pp 3-62.

27. Zerrouk, E. (2013). "Water grabbing/ land grabbing in shared water basins the case of Salween River Hatgyi Dam", Journal of Water Resources and Ocean Science, 2(5), pp 68-78. 